\title{
A reziliencia lehetséges értelmezése a településföldrajzi kutatásokban
}

\section{The interpretation of the concept of resilience for researches in urban geography}

\author{
PIRISI GÁBOR
}

PIRISI Gábor: adjunktus, Pécsi Tudományegyetem, Természettudományi Kar, Földrajzi és Földtudományi Intézet; 7624 Pécs, Ifjúság útja 6.; pirisig@gamma.ttk.pte.hu; https://orcid.org/0000-0003-0179-3228

KULCSSZAVAK: reziliencia; településfejlődés; modell; kisváros

ABSZTRAKT: A reziliencia koncepciója az elmúlt évtizedekben nagy utat járt be, mind az érintett tudományterületeket, mind pedig a vele összekapcsolt problémákat, kérdéseket tekintve. Az eredeti ökológiai problémafelvetés külső sokkokról és az egyensúly visszaszerzéséről szólt; a társadalomtudományok körében - beleértve a térrel foglalkozókat is - a hatások már nem egyszeri sokkok, hanem folyamatosan újratermelődő kihívások, ahol nem a soha nem létezett egyensúly visszanyerése a cél a komplex társadalmi rendszerek számára, hanem a kihívások és az adott válaszok révén történő fejlődés.

A tanulmány áttekinti a reziliencia fogalmi bővülését és átalakulását, valamint elhelyezi a társadalomföldrajz és a térrel foglalkozó tudományok számára leginkább felhasználható értelmezést ebben a szerteágazó rendszerben. A tanulmány felhívja a figyelmet a koncepció ellentmondásaira is, mindenekelőtt annak újdonságértékére, kritikaiságára és mérhetőségi problémáira. Teszi ezt azért, mert a létező és izgalmas itthoni interpretációk ellenére a fogalom még csak parciális jelentőségű a hazai területi kutatásokban. A tanulmány amellett érvel, hogy minden hibája ellenére a reziliencia fogalma alkalmas lehet arra, hogy segítségével a területi fejlődést újszerű módon értelmezhessük.

A tanulmány bemutat egy olyan elméleti modellt, amely elsősorban a hazai településhálózat, kiemelten pedig a (kis)városok vizsgálata számára jelenthet kereteket. A modell szerint a település politikai-önkormányzati, társadalmi és gazdasági szféráját érdemes vizsgálni annak a fényében, hogy ezek mennyire felelnek meg a diverzitás, kohézió és autonómia kritériumainak.

Gábor PIRISI: assistant professor, Institute of Geography and Earth Sciences, Faculty of Sciences, University of Pécs; Ifjúság útja 6., H-7624 Pécs, Hungary; pirisig@gamma.ttk.pte.hu; https:// orcid.org/0000-0003-0179-3228

KEYWORDS: resilience; local development; small towns; modelling

ABSTRACT: Resilience is an emerging concept from the broad spectrum of social sciences. Based on C. S. Holling's research, its primary interpretation - the response of complex ecosystems to

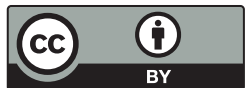


external shocks - has been transformed into divergent trajectories. In recent years, the concept of resilience has extended to the fields of various social sciences, including spatial sciences. Although the core of the original concept is still alive, there are significant differences in interpretation and application.

The present study attempts to summarize the main directions and approaches of the resilience concept with a double aim. On the one hand, it shows how the spatial sciences are influenced by resilience; on the other hand, it highlights the need for more complex interpretations, where complex systems can regain their stability not only after an unexpected shock from the economy, the environment or politics, but are also constantly forced to adapt to new challenges. Therefore, resilience in this research is interpreted as a social construction produced by a local community, based on systems of interlinked institutional and informal networks, including knowledge and skills carried by these networks, to enable continuous adaptation to the changing external socio-economic, political and ecological conditions.

Although there are some interpretations of resilience in the Hungarian social (sometimes even spatial) sciences, this concept is not yet a core element of discourses in human geography. Its wider use is perhaps hindered by some open questions: The study highlights the problem of novelty, the links to other concepts, the critical review and the uncertain measurability of resilience. Nevertheless, the study argues that resilience could be a relevant tool to reinterpret spatial development.

The last part of this study focuses on the possibilities of empirical work based on resilience. For this reason, the main features of a resilient settlement have been defined and a theoretical model introduced. The model recommends a survey of the local economy, society and governance, which should focus on three main characteristics: diversity, cohesion and autonomy. In addition, it briefly defines these characteristics in the various spheres of a locality, such as political-municipal, social and economic.

Although the model could theoretically be used for resilience-based research in a variety of locations, policy integration assumes the existence of local governance based on the principle of subsidiarity. For this practical reason, settlements with local governments are better suited for this research than larger units in Hungary. On the other hand, the demand for diversity was based on a relatively greater concentration of people and spatial activities, so that the model presented in the study is best suited for cities and not for villages.

\section{Bevezetés}

A tudományok, elsősorban a társadalomtudományok nem függetlenek a váratlanul felbukkanó és adott időszakban járványszerüen elterjedő innovációktól, amelyek közül néhány akár paradigmatikus átalakulás alapjának is bizonyulhat. Ilyen hullámok kapcsolódhatnak jelentősebb filozófiai-világnézeti átrendeződésekhez, érinthetnek - sokszor technológiai fejlődés nyomán elérhetővé vált új módszereket, de sokszor csak olyan új értelmezési keretet, fogalomkészletet jelentenek, amelyek lehetővé teszik ismert jelenségek más megközelítésből történő vizsgálatát, mélyebb megértését.

A reziliencia fogalmáról nem jelenthető ki egyértelműen, hogy mennyire tartósan épül be a társadalomtudományok fogalmi készletébe. Az sem egyértelmű, hogy önálló elméletként, különböző elméletekbe beépülő fogalomként vagy elemzési és esetleg fejlesztéspolitikai eszközként tekinthetünk-e rá. Annyi bizonyos, hogy közel sem új keletű fogalomról van szó, karrierje eredeti meg- 
közelítésében mintegy 45 éve indult, üstökösszerűnek legfeljebb - némi túlzással - a földrajzban és a regionális tudományban való felbukkanását tarthatjuk, de ebben az esetben is már évtizedes távlatról beszélhetünk.

A reziliencia fogalmát a legkülönbözőbb hátterü kutatók meglehetősen eltérő problémákra és módokon alkalmazták, élénk és igen tartalmas vitákat váltva ki, amelyek hozzájárulhatnak a területi folyamatok megértéséhez is.

Jelen tanulmány a rezilienciára mint a komplex (térbeli) rendszerek sajátosságára tekint, amely kiváló elméleti kerete a területi folyamatok elemzésének, illetve az e folyamatokba történő beavatkozás tervezésének. A tanulmány elsődleges célja az, hogy megtalálja a rezilienciaértelmezések közül azt, amelyik leginkább alkalmas e célra, és hogy elmélyítse a fogalom szerepét a hazai társadalomföldrajzi diskurzusban - hiszen a reziliencia mindezidáig szórványosan, bizonytalanul, nem explicit módon jelent meg. A kiindulópontot korábbi, a kisvárosok zsugorodását firtató vizsgálataim jelentették, amelyek a lényegében azonos kihívással találkozó települések eltérő helyi válaszaira hívták fel a figyelmet (Pirisi, Trócsányi 2015). Ennek a folyamatnak a mélyebb megértését szolgálja a reziliencia kisvárosi kutatásokba történő integrálása: a tanulmány egy olyan modellt vázol fel, amely alkalmas arra, hogy az elemzések hátteréül szolgáljon.

\section{Reziliencia: egy fogalom evolúciója}

A reziliencia tudományos karrierje Crawford Stanley Holling kanadai ökológus 1973-as tanulmányával indult (Holling 1973). Eredeti értelmében egy egyensúlyi állapotban lévő (komplex) ökológiai rendszer helyreállását jelentette valamely erőteljes külső behatás, sokk után. Sajátos, divergens evolúció során a reziliencia hol metaforaként, hol elméletként, hol konkrét stratégiaként egymástól különböző tudományterületeken jelent meg (Norris et al. 2008). Könnyebben áttekinthetők a jelenlegi fogalmi dilemmák, ha meghatározzuk a fejlődés legfontosabb irányait.

Az első irány a vizsgált jelenségek milyenségére vonatkozik. Noha Norris és munkatársai (2008), nyomukban pedig MacKinnon és Derickson (2013) is hangsúlyozzák a fizikai gyökereket, manapság ettől vagy az eredeti ökológiai alkalmazástól igen messze járunk. A fogalom párhuzamosan, de függetlenül terjedt el a pszichológiában (Robinson, Carson 2016), ahol nagyjából hasonló tartalommal, de individuumokra és csoportokra is alkalmazzák (Bonanno 2004; Werner 1989). A társadalomtudományokban az ökológiai megközelítés emberkörnyezet interakciókra való kiterjesztésével terjedt el a fogalom (Berkes, Folke 1998; Folke 2006); ezekben a rezilienciaalapú kutatásokban az ember nemcsak a külső hatások kiváltója, hanem azok elszenvedője is. A legtöbb, rezilienciával kapcsolatos kérdésfeltevés társadalmi csoportok külső hatásoknak való kitettségével, sérülékenységével, ellenálló vagy helyreálló képességével foglalkozik 
(Campanella 2006; Colten, Sumpter 2009; Keogh et al. 2011; Townshend et al. 2016), sőt, az az összefüggés is nyilvánvaló, hogy egy-egy nagy természeti katasztrófa, mint amilyen a Katrina hurrikán 2005-ben vagy a 2002-ben az Elbán levonuló „évszázad árvize” hozzájárultak a gondolatkör elterjedéséhez (Lang 2011). A természeti katasztrófák mellett hamar megjelentek az ember által létrehozottak is. A reziliencia bekerült a szeptember 11. utáni vitákba, pszichológiai (Bonanno 2004) és szélesebb társadalmi értelemben (Greenberg, Gotham 2008). A terrorfenyegetettség és a biztonság (Coaffee 2008) olyan ösvényeket nyitottak meg, amelyekkel a reziliencia átlépett a tisztán társadalomtudományi elméletek közé, sőt, bizonyos értelmezésekben úgy jelenik meg, mint a drámaian megnövekedett bizonytalanságú világ politikájának vagy kormányozhatóságának (governance) leginkább megfelelő vezérlő elv (Chandler 2014). Vannak kísérletek arra is, hogy a közösségek reziliens viselkedését átfogó térértelmezésbe integrálják, az autopoietikus működés részeként (Faragó 2017).

A jelentésbővítést és gondolati átvitelt megkönnyítette, hogy többen igyekeztek egységes keretbe foglalni az ökológiai és a születőben lévő társadalmi reziliencia fogalmait (Adger 2000). Holling (illetve szellemi múhelye) integratív elmélete pedig az ökológiai és társadalmi rendszerek ciklikus változásának és fejlődésének általános rendező elveit kívánta meghatározni (Holling 2001).

A kirakós utolsó jelentős, hiányzó darabját a 2008-ban kirobbanó gazdasági világválság hozta el, amikor a gazdaság (al)rendszereinek sérülékenysége vált központi kérdéssé (Plöger, Lang 2013; Wink 2014). A rezilienciát ettől kezdve városok és régiók gazdasági, illetve egyéb (például demográfiai) válságokkal szembeni ellenálló és megújuló képességének leírására is széles körben használták (Fejérdy, Karvalics 2015; Lang 2012; Simmie 2014; Tóth 2012).

A második fejlődési út szorosan kapcsolódik az elsőhöz: ahogy a reziliencia fogalma újabb és újabb területeket hódított meg, eredeti tartalma átalakult. Ma a tanulmányok jelentős része nemcsak azt szögezi le, hogy a fogalom bizonytalanságokat, párhuzamos értelmezéseket hordoz, hanem saját rezilienciaértelmezését is kénytelen kifejteni. A fogalmi sokszínűséget többen rendszerezték, ennek ellenére az eligazodni vágyó olvasó hamar meggyőződhet arról, hogy három- vagy két-, esetleg másképpen kétféle reziliencia létezik...

A leggyakrabban használt, háromféle típust használó megközelítés részben Holling gondolataihoz nyúlik vissza; legtöbbet hivatkozott, legtisztább formában ezt Ron Martin és Peter Sunley foglalta össze (2015). Ebben a megközelítésben megkülönböztetnek müszaki, (kiterjesztett) ökológiai valamint adaptív rezilienciát (1. ábra). A három fogalom három különböző ellenálló és reakcióképességet takar:

a) A műszaki reziliencia egy rendszer stabil alapállapotba való visszatérésének képességét („,visszapattanását”) jelenti, és kifejezhető azzal az idővel, amely a behatás és a működés helyreállása között eltelik.

b) Az ökológiai reziliencia annak a maximális külső hatásnak a mértéke, amelyet a rendszer még károsodás vagy jelentős állapotváltozás nélkül képes elviselni, voltaképpen abszorpciós képesség. 
1. ábra: A reziliencia típusai

Types of resilience

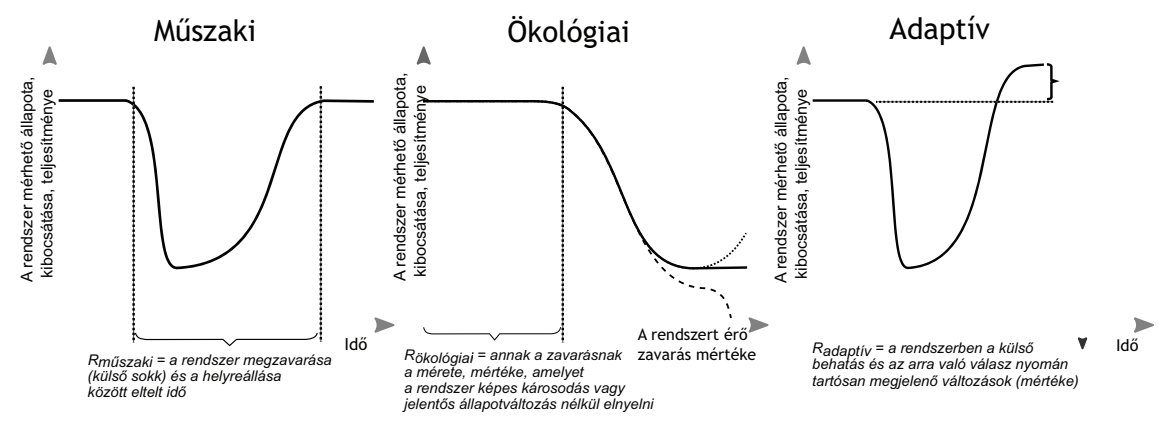

Forrás: Martin, Sunley (2015) és Martin (2012) felhasználásával saját szerkesztés.

c) Az adaptív reziliencia olyan képességre utal, amelynek révén a rendszer külső behatásokra megváltozik, avagy a megváltozott külső körülményekhez adaptálódik.

Látható, hogy két hasonló (a és b), és egy eltérő fogalomról van szó: az első két esetben a reziliencia a rendszer valamely adott, a behatás pillanatában meglévő tulajdonsága, a harmadik esetben viszont a behatás kapcsán bekövetkezett megváltozása. Az első kettő (elvileg) jól mérhető, a harmadik nehezen számszerüsíthető, hiszen egy olyan komplex rendszerben bekövetkező változás, amely nem írható le néhány változó számszerü különbségeként. Ilyen értelemben az ábra jobb oldala talán túlzottan leegyszerüsítő.

Rezilienciája úgyszólván bárminek lehet. Az ökológiai reziliencia fizikai megközelítésben (mint erőelnyelő képesség) viszonylag egyszerű „rendszereknek" is fontos, tesztelt és növelni vágyott tulajdonsága, mint mondjuk egy széknek. A komplex rendszerek, amelyek közül Walker et al. (2004) megkülönböztetnek tisztán természeti, tisztán társadalmi, kombinált, valamint szocioökológiai típusúakat, szükségképpen mindegyikkel rendelkeznek valamilyen mértékben. Azonban a társadalomtudományokban a harmadik megközelítés vált uralkodóvá, így többen, például MacKinnon és Derickson (2013) két típust állítanak egymással szembe: az elasztikusságot és a visszatérés sebességét (voltaképpen $a+b)$, illetve a rendszer adaptációs folyamatát.

Előbbitől némileg eltérő duális megközelítés Chandler (2014) munkája, amely klasszikus és posztklasszikus rezilienciát különbözet meg. Az előbbiben egyértelműen elkülönül a külső behatás és az azt elszenvedő egyén (vagy rendszer), amelynek a belső tulajdonságai teszik lehetővé a külső behatás „túlélését", legyen az a hatások elnyelése-elviselése, a visszapattanás vagy a felépülés. A másik megközelítés összekapcsolja az egyén vagy a rendszer szempontjából „külső” és „,belső” tulajdonságokat, amelyek egyszerre részei a kihívásnak és a válasznak. A rendszerek így alkotói és termékei a folyamatnak, a nyílt végű adaptációs folyamat nemcsak a rendszer változásáról, hanem a folyamat világot 
megváltoztató szerepéről is szól. Más megközelítésben: nyoma sincs „új egyensúlynak", csak olyan összekapcsolódó változásoknak, amelyek minduntalan új válságok kiindulópontjai lesznek.

Jelen tanulmány kiindulópontja ezen összetett, a folytonos adaptációt elötérbe helyező komplex rezilienciafogalom. Olvasatomban a reziliencia társadalmi konstrukció, amelyet egy térbeli alapon szervezödö, intézményesült és informális kapcsolatok által összekapcsolt közösség hoz létre. E kapcsolatok által hordozott készségek és tudás összessége, amely lehetővé teszi a változó, a közösség szempontjából külsődleges társadalmi, gazdasági, politikai és ökológiai feltételekhez való folyamatos alkalmazkodást, a közösség müködöképességének megörzését, a képességet a saját készségek és tudás bővitésére és struktúra megújitására, ezáltal a közösség kiszolgáltatottságának csökkentésére. A reziliencia e meghatározása természetesen nem kizárólagos, de a tanulmány további részében az elméleti dilemmák, valamint a felvázolt modell elvi alapját képezi.

\section{Hazai rezonanciák}

Talán országunk szerencsés, természeti katasztrófák szempontjából biztonságos fekvése, alacsony kitettsége is hozzájárul ahhoz, hogy a reziliencia csekély nyomot hagyott a hazai társadalomtudományokban (kivételek a pszichológia és talán a pedagógia magyar nyelvű alkalmazásai). A tipikus területek közül a katasztrófavédelem szinte teljesen hiányzik, és az ökológiában is csak olyan elméleti fejtegetéseket leltem fel, amelyek a rezilienciát mint új jelenséget (új tudományos narratívát) a fenntarthatóság szemszögéből elemzik (Bándi 2013; Békés 2002; Szokolszky, Komlósi 2015).

A társadalomföldrajz szempontjából fontosabb alkalmazások néhány szerzőhöz, illetve egy-egy alkalomhoz kötődnek. Kiemelkedik a Replika folyóirat 2015. évi 94. száma, amelyben többek között társadalomtörténeti (Majtényi 2015), illetve urbanisztikai (Fejérdy, Z. Karvalics 2015) megközelítéseket olvashatunk. A legjelentősebb tanulmány Székely Iván (2015) összegzése, amely áttekinti a reziliencia értelmezési lehetőségeit és társadalomtudományi alkalmazásainak legfontosabb állomásait. A regionális tudományban az elméleti, filozófiai irányzatot Faragó László képviseli (2017), aki az adaptív megközelítésủ rezilienciát az autopoietikus működés alrendszereként határozza meg.

Gyakorlatiasabb megközelítésűek azok a tanulmányok, amelyek a területi vagy regionális rugalmasságot vizsgálják, jellemzően statisztikai módszerekkel (Tóth 2012, 2015). Szerzőjük az általa vizsgált jelenségekre az angol kifejezésekben meglévő párhuzamosságot (resilience, flexibility, elasticity) kívánta feloldani a magyar kifejezés használatával. Explicitebb, kiterjesztett értelemben használja a kifejezést Szabó Béla (2015), aki nemcsak a társadalmi tőkével (olvasatában: kapcsolati hálóval) összefüggő kutatások során, hanem programként is hangsú- 
lyozza a reziliencia fontosságát. A jelen tanulmányhoz leginkább közel álló hazai értelmezés Lendvay Mártoné (2016), aki egy rurális térség sajátos közösségében vizsgálja a reziliencia mintázatait.

Röviden összegezve, a hazai rezilienciavizsgálatokat elsősorban a pszichológiai dominancia, az alacsony darabszám, a terminológiai sokszínűség és bizonyos témák hiánya jellemzi. Biztató, hogy többen felismerték a koncepció rugalmas alkalmazhatóságát, elméleti és gyakorlati problémákra egyaránt.

\section{Nyitott kérdések és dilemmák}

A reziliencia koncepciójának felkapottá válása, gyors tartalmi bővülése és evolúciója távolról sem jelenti, hogy ne lennének élénk, a jelenséget sokszor alapjaiban megkérdőjelező viták és nyitott kérdések. A jövőbeni alkalmazásoknak ezeket valamiképpen kezelni kell. A kritikai megnyilvánulások sokszínűek, nem sorolhatók be egyetlen elméleti paradigma vagy gyakorlati szempont mögé: egyszerre vannak jelen a koncepció (vélelmezett) negatív értéktartalma miatti markáns elvi elutasítások, valamint a gyakorlati felhasználást megkérdőjelező módszertani megközelítések.

\section{Régi bor - új palackban?}

A reziliencia fogalma fejlődése során interakcióba került más elméletekkel. Tudatosságot is felfedezhetünk amögött, ahogy integratív koncepcióvá válva müvelői növelték ezen interakciók és átfedések számát. Ugyanakkor a rezilienciának más, hasonló területekhez való viszonya nem tisztázott.

A leginkább kritikus pont a fenntartható fejlődéssel kapcsolatos viszony. Több szerző úgy érvel, hogy reziliencia mint általános érvényű narratíva felváltja a fenntarthatóságot (Kaltenbrunner 2013), hogy elérkezik a rezilienciaalapú városfejlesztés kora (Sieverts 2013). Ezeknek az érveléseknek fontos eleme, hogy a fenntarthatóság protektív-konzervatív, ezzel szemben a reziliencia dinamikus (Stumpp 2013), illetve hogy a fenntarthatóság mint végső cél helyett a rezilienciára mint oda vezető útra terelődik a figyelem (Barata-Salgueiro, Erkip 2014; Callaghan, Colton 2008). A legtöbb ilyen érvelés nem elméleti, hanem gyakorlati oldalról közelíti meg a problémát, a közösségfejlesztés hétköznapi kihívásai felől (Barr, Devine-Wright 2012). A fenntarthatósági elvek megfogalmazása már-már magától értetődővé vált a tervezésben (Stumpp 2013), de mivel távoli és a maga teljességében a közösségek többsége számára soha el nem érhető célra fókuszált, a mindennapok kihívásairól keveset mondott. A területi-települési politika, fejlesztés és tervezés számára a reziliencia gyakorlatiasabb fogódzókat kínál, amikor az adaptációval apró sikereket (vagy katasztrófák, nagyobb kudarcok elkerülé- 
sét, „szorosabb” vereséget) ígér. Nem utolsósorban a reziliencia felfogása a bizonytalan jelenről, a cseppfolyós, nem lineáris, megjósolhatatlan jövőről (Chandler 2014) és az emiatt érkező újabb és újabb kihívásokról talán közelebb áll a hétköznapi emberek jellemző valóságérzékeléséhez („majd azt is megoldjuk valahogy, csak jussunk el odáig").

Elméleti oldalról Holling és mások is igyekeztek összekapcsolni a fenntarthatóság és a reziliencia fogalmát. Holling (2000) szerint a fenntarthatóság az adaptív képesség megteremtésére, tesztelésére és fenntartására vonatkozó kapacitás, míg a fenntartható fejlődés az adaptív kapacitások növeléséről és lehetőségek teremtéséről szól. A fenntartható jövőben az emberi megélhetés egyszerübb, a választható lehetőségek bőségesebbek és a természet diverzitása jobban, sikeresebben megőrzött - mindezt pedig a társadalmi és a természeti rendszerek adaptációs képessége tenné elérhetővé (Holling 2000). A reziliencia lenne tehát az az eszköz, amelynek révén a közösségek haladhatnak a fenntarthatóság felé (Barr, Devine-Wright 2012; Colding, Elmqvist, Olsson 2003; Szokolszky, Komlósi 2015). Ebben az értelemben a reziliencia sem nem felváltója, sem nem antitézise, inkább logikus kiegészítése és továbbfejlesztése a fenntarthatóságnak (amely bizonyos müvelőinek szent meggyőződése ellenére sem lehet valamiféle végső tudományos narratíva).

Természetesen vannak más „érintkezési felületek” is, amelyek tisztázásra szorulnak. Összekapcsolták a rezilienciát például az útfüggőség, a tanuló régiók, valamint az evolúciós közgazdaságtan elméleteivel. Az útfüggőség megjelenik egy adott helyzetre adható válaszok lehetséges számában (Walker et al. 2004), az adaptáció lehetőségeiben és korlátaiban (Robinson, Carson 2016). Mélyebbre ásva gyakran emlegetett elemek a humán és intézményi kapacitások, ezek összekapcsoltsága és rugalmassága - ezeket többé-kevésbé a tanuló régiók (települések) koncepciójában is előszeretettel hangsúlyozzák (Molnár 2014), gyakran tudatosan összekapcsolva a kettőt (Tschakert et al. 2014). Tágabb perspektívában a reziliencia és az evolúciós közgazdaságtan kapcsolatának tisztázására is történtek erőfeszítések. Ron Martin (2012) azt hangsúlyozza, hogy a reziliencia adaptív értelmezése segít a régiók gazdasági folyamatainak leírásában, Robert Hassink (2010) a kételyeit fejezi ki annak kapcsán, hogy hozzáad-e valamit a reziliencia a már meglévő értelmezési lehetőségekhez. Előbbi álláspont a többségi, a reziliencia beépülni látszik az evolúciós közgazdaságtan fogalomkörébe (Boschma 2015; Reggiani, Graaff, Nijkamp 2002; Simmie, Martin 2010).

\section{Értékek és érdekek - mégis, kinek a rezilienciája?}

Mióta a reziliencia fogalma beszivárgott a társadalomtudományokba, aránylag heves a vita arról, hogy meg lehet-e közelíteni normatív alapon, kapcsolódhat-e hozzá értékítélet. Mindmáig domináns értelmezés az, hogy a reziliencia pozitív tartalmú fogalom. Voltaképpen miért is ne lenne jó, ha a közösségek és rendszerek rugalmasabbak, válságállóbbak és szervezettebbek? 
Ehhez képest a kritikai megközelítések kifejezetten erőteljesek és hevesek. A legfőbb probléma szerintük, hogy a közösségek rezilienciáját fejlesztéspolitikai célként meghatározó megközelítések az állami szerepvállalás hiányait pótolják - segíts magadon, mert más úgy sem fog. MacKinnon és Derickson (2013) három pontban foglalták össze e kritikák lényegét: 1. a reziliencia konzervatív koncepció, tehát a fennálló struktúrák megőrzésére irányul; 2. kívülről definiált, vagyis külső szakértők határozzák meg a közösségek számára, hogy mit jelent reziliensnek lenni; 3. téved a léptékkel kapcsolatban: a legfontosabb problémákat és kihívásokat nem lehet helyben kezelni. Ez utóbbi problémát nevezi Peck és Tickell (2002) hatalom nélküli felelősségnek - ebben az olvasatban a reziliencia a kritikai geográfusok által hevesen elutasított neoliberális politikai, kormányzati és társadalmi modellek újracsomagolása. Swanstrom (2008) nyomán számos kutató kiemeli, hogy a reziliencia „karrierje” azzal párhuzamosan emelkedett, ahogyan az állam ideológiailag is alátámasztott visszavonulása megkezdődött (Strange 1996).

Ezzel párhuzamosan felvethető a kérdés, hogy mit jelent egy közösség rezilienciája (Cutter 2016). A rendszerek oldaláról nézve a reziliencia olyan esetekben vagy olyan áron is biztosítja a fennmaradást, amely a rendszert alkotó egyének és közösségek kárára van - Székely Iván (2015) példái az elnyomó politikai rendszerek szívós fennmaradásáról napjainkban Kínában és Oroszországban nagyon életszerüek. Más megközelítésben a reziliencia nem egyszerüen sajátossága, hanem erőteljes eszköze (a biztonság és a kockázat fogalmaival egyetemben) a rendszerek fenntartásának (Watts 2016).

Ha előbbi érvelést teljes egészében elfogadnánk, akkor az elutasítás volna a helyes kutatói magatartás. Ugyanakkor a kritikai megközelítéssel szemben a szakirodalom jelentős része úgy véli, hogy a reziliencia mint jelenség alapvetően és eredendően értéksemleges, nem normatív, hanem elemzésre használt fogalom (Adger 2000; Deppisch 2016). Ha úgy tetszik: segít megérteni az összetett rendszerek müködését, és az elemzés során nyert adatokat különböző értékválasztás szerint is fel lehet használni. Azonban amellett is lehet érvelni, hogy a reziliencia felruházható, felruházandó pozitív értéktartalommal. Lehet, hogy rossz kérdést teszünk fel, amikor „elvétve a léptéket” azt keressük, mit tehetnek a közösségek olyan problémák orvoslása érdekében, amelynek kialakulásáért nem (ők) felelősek. Ugyanakkor a reziliencia fontos alapelve a kiszolgáltatottság csökkentése, amely egy fennálló külső feltételrendszeren belül lehetővé teszi a jobb boldogulást. Tehát a társadalomföldrajz nézőpontjából foglalkozni kell a reziliencia „alulról jövő" értelmezésével, amely a vizsgálatok középpontjába a közösséget állítja, nem pedig a rendszert. Nem a stabilitás minden áron való megőrzésére összpontosít, hanem a pozitív változások, a fejlődés, tanulás lehetőségét kínálja. A reziliencia fogalmát a területi vizsgálatokba és a tervezésbe integrálva jelentős előrelépést érhetünk el, amelynek hozadéka nem csak egy szűk rétegnél jelentkezik. 


\section{Mi harminc? Mi mennyi?}

Ez utóbbi célt csak akkor lehet elérni, ha a rezilienciát legalább közelítőleg mérni tudjuk; az egyes közösségek közötti különbségeket és az időbeli változásokat leíró eszközöket találunk.

A reziliencia méréséről nincs tudományos konszenzus, ami nem meglepő annak fényében, hogy mennyire összetett jelenségről van szó. A rezilienciakutatások operacionalizálása is kihívások elé állítja a kutatókat, akik ritkán vállalkoznak a jelenségek számszerűsítésére. Ha pedig mégis, akkor igyekeznek olyan küszöbértékeket meghatározni, amelyek a reziliencia szempontjából kritikusak - ez elsősorban az ökológiai értelmezések sajátja; vö. 1. ábra (Deppisch 2016). Carpenter, Westley és Turner (2005) helyettesítő tényezők bevezetését javasolják, amelyek közelítik a reziliencia fogalmát és mérhetőek. Ezek kiválasztásához stakeholderelemzést, modellalkotást, történeti és esettanulmányokat tartanak szükségesnek.

Leszámítva a módszertanilag kidolgozottabb pszichológiai-pszichiátriai irányvonalat, a legtöbb kísérletet a katasztrófavédelemből ismerjük, ahol a számszerüsítés alapvető fontosságú (Somers 2009; Tierney, Bruneau 2007). Ennek a folyamatnak a legfontosabb és nem kielégítően megoldott eleme a reziliencia modellezése. A végeredmény gyakran olyan, rengeteg elemmel és léptékkel számoló komplex megközelítés, amely aligha alkalmas összehasonlító vizsgálatokban való alkalmazásra (Renschler et al. 2010).

A komplex rezilienciaértelmezéseket használó kutatások általában esettanulmányok. Az esettanulmányok döntően kvalitatív módszertana kiválóan alkalmas arra, hogy feltárja a vizsgált közösségek azon immanens sajátosságait, amelyek a reziliens reakció képességét kialakítják. Éppen ezért jelentőségük kimagasló, és fontos lenne, hogy az egyetlen jelentős, általam ismert példán túl (Lendvay 2016) továbbiak is készüljenek Magyarországra is. Az esettanulmányok összehasonlító vizsgálatokra is lehetőséget adnak: a vizsgálatba vont közösségek összevethetők a részvétel, a bizalom, a kapcsolati hálók sűrűsége, a helyi szereplők közötti kommunikáció és együttmüködés formalizált és informális mintái szempontjából - ezek értékelhetően mutathatnak be esetek közötti különbségeket.

Kapcsolódhat-e a kvalitatív-lokális módszertanhoz kvantitatív-generális megközelítés? Ehhez szükségesek lennének olyan területi adatsorok, amelyek a reziliencia tényezőinek jelenlétére utalnak. A hazai viszonyok ismeretében óvatos szkepszissel élhetünk, különös tekintettel arra, hogy egy ilyen adattömeg mennyiben vezetné tévútra a kutatásokat pusztán tartalmának bizonytalansága vagy éppen azok ténylegessége miatt. Mégis, bizonyos adatbázisok - például a nonprofit szféráról (az „1\%-os” adatbázis), a helyi politikai színtér jellegéről (választási adatok), a fejlesztéspolitikáról (támogatási adatok) - alkalmasak lehetnek arra, hogy azokból óvatos területi következtetéseket vonjunk le. Járható út lehet az is, hogy a rezilienciát olyan rendszertulajdonságnak te- 
kintjük, amelynek megléte vagy hiánya néhány, a rendszer általános müködését leíró mutatóban tükröződik, amelyek kifejezik egy külső sokkra adott reakció rugalmasságát. Ez ugyan a reziliencia valamivel szúkebb értelmezése, de ilyen mutatót használt Alpek és Tésits (2014) a fragilitás mérésekor. Összességében azonban nem az univerzális rezilienciaindex megalkotására kellene törekedni, hanem a kis léptékü, longitudinális vizsgálatokra, amelyekben a reziliencia változását fel lehet mérni.

\section{Települési szintü fejlődési problémák a reziliencia szemüvegén keresztül}

A rezilienciát mint a bizonytalan jelen és a még bizonytalanabb jövő kihívásainak való rugalmas megfelelés doktrínáját sokan és sokféle kontextusban használták a területi fejlődés problémáinak vizsgálatakor. Településföldrajzi kiindulópontból kérdés, hogy képes-e a reziliencia új értelmezést adni a települések fejlődéséről folyó diskurzusnak. Sőt, az a kérdés is joggal fogalmazható meg, hogy a település alkalmas szint-e reziliencián alapuló elemzések elkészítésére.

Arra elegendő példát láthattunk, hogy a település a rezilienciával kapcsolatos vizsgálatok alapját képezi - bár ez a megközelítés nem kizárólagos, talán nem is domináns. Számos vizsgálat alanya egy-egy kisebb, viszonylag homogén vagy nagyobb településcsoport. A gazdaságföldrajzi megközelítések általában a régiót emelik vizsgálatuk fókuszába.

Az ideális lépték megválasztása elsősorban azon múlik, milyen tényezőket és milyen kihívásokat tekintünk a rezilienciavizsgálatok kulcsának. A rezilienciával sokszor összekapcsolt faktorok közül az összekapcsoltság, a kohézió, a bizalom, az informalitás teremtette rugalmasság biztosan csökken a lépték növekedésével. Ugyanakkor az erőforrások feletti irányítás (elvi és gyakorlati) lehetősége, a közösség rendelkezésére álló eszköztár nyilvánvalóan növekszik, ha az elemzés szintje a nagyobb egységek irányába tolódik el.

Ezzel együtt meghatározhatók egy térhez kötődő közösség rezilienciájának küszöbfeltételei. Az egyik, hogy a közösségnek az önszerveződés, az önigazgatás, az önkormányzás jegyeit kell mutatnia: formális vagy informális módon képes döntéseket hozni saját magáról. Fontos hangsúlyozni, hogy ehhez nem feltétlenül szükséges a szó közjogi értelmében vett önkormányzás. A második küszöbfeltétel a rendelkezésre álló erőforrások mennyisége és sokfélesége: minimális méret, illetve az erőforrások átcsoportosításának legalább elvi lehetösége. További fontos elem az identitás, hiszen a reziliencia kutatásakor olyan konstrukciókra van szükség, amelyekkel a társadalmi csoport azonosulni képes. Ez a kritérium elsősorban minőségi, mintsem mennyiségi: olyan térbeli egységeket kell keresni, amelyek organikus fejlődés eredményeként jöttek létre, és nem tekinthetők pusztán a fejlesztési vagy a kutatói percepció termékeinek. 
A település mint elemzési szint Magyarországon a legjobb kompromisszumnak, optimális keretnek tűnik. Előbbi kritériumok közül önkormányzatisággal a területi szintek közül érdemben a települési vagy a nemzeti szint rendelkezik. Az identitásról több hazai szerző (Gyáni 2008; Murányi, Szoboszlai 2000; Pap 2014) hangsúlyozza a települési szint fölényét más szintekhez képest. Sokkal bonyolultabb megítélni az erőforrások mennyiségére és minőségére vonatkozó paramétereket. A magyarhoz hasonló társadalmakban a globális szinttől való gazdasági függőség illuzórikussá tesz minden ilyen fejtegetést. Alacsonyabb szinten az önkormányzatiság kiüresítése és a döntéshozatal centralizálása (Pálné Kovács et al. 2016) vethet fel kételyeket. A hazai realitásokat elfogadva is van értelme a küszöb meghatározásának, hiszen a legkisebb települések által meghatározott rurális térségekben nemcsak az erőforrások minimális száma és alacsony diverzitása jelent problémát, hanem a falusi települések funkcióvesztésével a települési kohézió megszűnése is: a térbeli interakciókból kizáródott, ingázni vagy az elemi fogyasztási célok kielégítéséhez eljárni képtelen csoportok leszakadhatnak (Alpek, Máté 2018), a lokális identitás gyengülhet.

A funkcionalitásukat még megőrzött településeken, ahol van helyi munkaerőpiac és vannak alapvető szolgáltatások, az interakciók elsődleges tere a település. A kisvárosi méretkategóriába tartozó, legalább 1000, maximum 10 ezer munkavállalónak otthont adó településeken a helyben dolgozók aránya 2011-ben 59\%-os volt; a 2001-es népszámláláskor 73\%-os volt a helyben tanulás aránya alap- és középfokon. A térbeli interakciókat középpontba állító diverzitáskutatások is általában a települést tekintik meghatározó keretnek (Kovács, Szabó 2017; Németh, Dövényi 2014; Reményi 2009).

Hazai viszonyok között tehát az igazgatási és kohéziós érv a települések, az erőforrásokkal kapcsolatos érv pedig a „kellően nagy” települések felé tereli a kutatót. A kisvárosok viszonylagos kompaktságát, a formális mellett az informális kapcsolatok helyi koncentráltságát, valamint a településhez való erős kötődést korábbi kutatásaim is megerősítették (Pirisi 2017). Magyarországon vélhetően a kisvárosok jelenthetik a legalsó olyan kategóriát, amelynek a reziliencián alapuló elemzése, fejlesztése eredményes lehet - ami nem zárja ki más, a területi hierarchiába nem illeszkedő társadalmi csoportok, illetve más körülmények között ettől eltérő szintek eredményes vizsgálatát.

\section{Egy reziliens település alapvonásai}

Ha az eddigiekben leírtakat elfogadjuk, vagyis hogy a reziliencia a települések fejlődésének sajátos aspektusa, illetve olyan társadalmi konstrukció, amelyet intézményesült és informális kapcsolatok által összekapcsolt, térbeliséggel leírható közösség hoz létre, valamint lehetővé teszi a változó, a közösség szem- 
pontjából külsőnek tekinthető társadalmi, gazdasági politikai és ökológiai feltételekhez való folyamatos alkalmazkodást, akkor meg kell határoznunk, hogy milyen sajátosságai vannak egy reziliens településnek.

Olyan általános tulajdonságokat keresünk, amelyek feltételei a reziliencia létrejöttének. A rugalmas alkalmazkodást kialakító tényezőket a helyi társadalom szűkebben értelmezett belső, strukturális sajátosságaiban, a piaci és nem piaci viszonyok által meghatározott gazdasági aspektusban, valamint a belső tagoltságot és a külső kapcsolatrendszert egyaránt meghatározó politikai dimenzióban kereshetjük.

A korábbiakban bemutatott elméleti alapok, a társadalomtudományok rezilienciával kapcsolatos vizsgálatai lehetővé teszik a reziliencia kulcstulajdonságainak meghatározását; a nehézséget az okozza, hogy a legtöbb kutatás általában csak egy-egy társadalmi szférát, egy-egy aspektust emel ki.

A legbiztosabb elem a diverzitás. Az ökológiai gyökerű rezilienciafogalom kezdetektől pozitívumként értelmezte a diverzitást - eredetileg biológiai értelemben (Holling 1986), de később a társadalmi analógiák felé is nyitva (Adger 2000; Elmqvist et al. 2003). Az utóbbi években a diverzitás jelentőségét különböző kiindulópontokból hangsúlyozzák (Boros et al. 2016; Németh 2016).

Aligha vitatható, hogy a kohézió szerepe is jelentőséggel bír. Ezt az aspektust a társadalomtudományi kutatások hozták előtérbe, például a katasztrófahelyzetbe került közösségek reakciója kapcsán (Adger et al. 2005; Townshend et al. 2016; V. Komlósi, Richter 2015). A kohéziót más szerzők alapvetően a társadalmi tőkében látják kifejeződni (Aldrich, Meyer 2015; Petzold 2016; Szabó 2015), megint más megközelítésekben az összekapcsoltság jelenik meg (Ahern 2011), amely ugyan nem azonos a kohézióval, de a társadalmi csoportok közötti interakciók révén rokon természetü.

A harmadik tulajdonság az autonómia. Korábban röviden érveltem a helyi döntéshozatal és reziliencia kapcsolata mellett, amely a kihívásokra való tudatos stratégiaalkotás és válaszadás lehetőségeit jelenti. Az autonómia központi szerepet játszik a közösségi „leleményesség” (resourcefulness) koncepciójában (MacKinnon, Derickson 2013), de megjelenik más kontextusokban is, mint a katasztrófasérülékenység csökkentésének eszköze (Tanner, Mitchell, Polack 2009) vagy a mentális ellenálló képesség egyik feltétele (Kirmayer et al. 2011).

Ha kételkednénk a három kiválasztott tulajdonság jelentőségéről, érdemes megfordítanunk a kérdést: vajon egy közösség, amely társadalmában, gazdaságában és politikumában egyveretű, polarizáltság és szétszakítottság jellemzi, valamint ki van zárva a saját sorsát érintő döntéshozatalból, nem tekinthető eleve igen sérülékenynek?

A fenti tulajdonságok - a rezilienciát kialakító tényezők - értelmezhetők a három, korábban megnevezett szférában: a társadalom strukturális viszonyaiban és a reciprocitáson alapuló kapcsolatrendszereiben, a gazdasági aktivitásban és a piaci viszonyrendszerekben, valamint a politikai szférában és a hatalmi/alárendeltségi viszonyokban (1. táblázat). 
1. táblázat: A reziliens település sajátosságai a helyi társadalom néhány viszonyrendszerében Attributes of the resilient settlement in some spheres of the local community

\begin{tabular}{|c|c|c|c|}
\hline \multirow{2}{*}{$\begin{array}{c}\text { A helyi társadalom } \\
\text { tértermelésének } \\
\text { aspektusai }\end{array}$} & \multicolumn{3}{|c|}{ A rezilienciát kialakító legfontosabb tényezök } \\
\hline & Diverzitás & Kohézió & Autonómia \\
\hline $\begin{array}{l}\text { Társadalmi } \\
\text { struktúrák és } \\
\text { reciprocitáson } \\
\text { alapuló } \\
\text { viszonyok }\end{array}$ & $\begin{array}{l}\text { Sokszínűség, heterogén } \\
\text { szerkezet a társadalom } \\
\text { különböző metszeteiben } \\
\text { (kor-, státusz-, etnikai és } \\
\text { vallási tagoltság, } \\
\text { szubkulturális és } \\
\text { életmódcsoportok }\end{array}$ & $\begin{array}{l}\text { Erős kötődés a helyi } \\
\text { közösséghez (identitás), } \\
\text { magas szintű társadalmi } \\
\text { tőke (bizalom), integráció: } \\
\text { a kirekesztés és a } \\
\text { kizáródás hiánya }\end{array}$ & $\begin{array}{l}\text { Önszervezettség, jelentős } \\
\text { számú alulról jövő } \\
\text { kezdeményezés és } \\
\text { nonprofit szervezet } \\
\text { jelenléte, működése }\end{array}$ \\
\hline $\begin{array}{l}\text { Gazdasági } \\
\text { aktivitás és piaci } \\
\text { viszonyok }\end{array}$ & $\begin{array}{l}\text { A gazdasági szereplők } \\
\text { méretbeli és ágazati } \\
\text { sokszínűsége }\end{array}$ & $\begin{array}{l}\text { Helyi kötődésű } \\
\text { vállalkozások jelenléte és } \\
\text { társadalmi szerepvállalása }\end{array}$ & $\begin{array}{l}\text { A gazdasági aktivitás } \\
\text { erőforrásainak helyi } \\
\text { rendelkezésre állása, helyi } \\
\text { piacok működése, lokális } \\
\text { termelési láncok és piaci } \\
\text { kapcsolatok }\end{array}$ \\
\hline $\begin{array}{l}\text { Politikai aktivitás } \\
\text { és hatalmi } \\
\text { viszonyok }\end{array}$ & $\begin{array}{l}\text { Értékpluralizmus, } \\
\text { különböző csoportok } \\
\text { részvétele a } \\
\text { döntéshozatali } \\
\text { mechanizmusokban, a } \\
\text { kisebbségi vélemények } \\
\text { artikulálásának } \\
\text { lehetőségei }\end{array}$ & $\begin{array}{l}\text { Érdekegyeztetési } \\
\text { mechanizmusok } \\
\text { müködése, } \\
\text { együttmüködés a } \\
\text { különböző csoportok } \\
\text { között az alapvető } \\
\text { stratégiai célok kapcsán }\end{array}$ & $\begin{array}{l}\text { A helyi ügyeket érintő } \\
\text { stratégiaalkotás és } \\
\text { döntéshozatal széles körü } \\
\text { szabadsága }\end{array}$ \\
\hline
\end{tabular}

Ez a társadalom tértermelésén, illetve a reziliencia tényezőin alapuló modell a közösség belső viszonyrendszereire fókuszál, ezért kiegészítést szükséges hozzá tenni, mivel a helyi társadalom regionális, nemzeti és globális rendszerekbe integráltan létezik. Ezek mindegyikét nem lehetséges felsorolni, de szükséges nevesíteni a természeti aspektust, amely globális léptékben bioszféraként, lokális léptékben tájként vagy települési környezetként jelenik meg. Ideális esetben az ehhez való viszonyulást a fenntarthatóság határozza meg (Hajnal 2006). A gazdasági aspektusban a globális, világpiaci lépték egyre dominánsabb volta mellett továbbra is fontos szerepet játszik a regionális dimenzió: alapvetően az integráltság mértéke határozza meg e kapcsolatok jellegét. Politikai aspektusból (erős nemzeti, sokkal gyengébb szupranacionális dimenziókkal) a hozzáférés lehet döntő, amely összekapcsolja a helyi közösségeket a döntéshozatali folyamatokkal.

A táblázatban a diverzitás, a kohézió és az autonómia lehetséges aspektusai, megjelenési formái szerepelnek, amelyeket egy település keretei között értelmezünk. Fontos hangsúlyozni, hogy a reziliens település szükségképpen nyitott rendszer: amikor autonómiáról beszélünk a politikában vagy a gazda- 
ságban, semmiképpen sem szabad elszigeteltségnek vagy autarkiának értelmezni azt. Ugyanígy: a kohézió nem jelentheti a rendszeren kívül álló szereplők kirekesztését, a diverzitás pedig nem jelentheti a közös értékek és az azonosulás teljes hiányát. Az egyes tényezőknek inkább az optimális, semmint a maximális szintjét kell kialakítani.

Az egyes tulajdonságok nem maximalizálhatók anélkül, hogy ne váltanának ki csökkenést egy vagy több másik tényezőben. Például a diverzitás növekedése a társadalomban sajátos kihívásokat támaszt a kohézió számára: nehezebb lesz kialakítani azt az értékközösséget, amely egy zártabb, homogénebb csoportnál öröklött tulajdonságként szinte magától megjelenhet. Még a gazdasági életben kívánatos diverzitásnak is lehet olyan szintje, amelynél a helyi szereplők kimaradnak bizonyos, a regionális klaszterek révén realizálható versenyelőnyökből. Megfordítva azt is könnyü belátni, hogy egy kohézióját maximalizáló közösség könnyen válik elzárkózóvá és kirekesztővé a kívülről jövő emberek, ideák és szereplők irányába, ami a verseny és az innovativitás kizárását is jelenti, és nem a rezilienciát, hanem a törékenységet fogja növelni. Hasonló eredménnyel járhat a gazdasági autonómia maximalizálása, hiszen ez autark gazdasági rendszert jelent. Lehet ugyan amellett érvelni, hogy az autarkia praktikus lehet a legkisebb településeken, ugyanakkor nagyon nehézzé válik az erőforrások hosszú távú bővítése, illetve pótlólagos erőforrások mozgósítása gyors, hirtelen támadt kihívások esetén. Hasonlót lehet elmondani a politikai értelemben vett autonómiáról is: a saját ügyekben történő döntéshozatali szabadság és mozgástér szükséges, ugyanakkor egy bizonyos szinten túl a nagyobb rendszerekbe való integráltság hiánya a kiszolgáltatottságot fokozza.

A fenti modell általános, vagyis mérettől és földrajzi helyzettől függetlenül próbálja rendszerbe foglalni a települések rezilienciáját kialakító háttértényezőket. Ugyanakkor olyan fogalmakat használ, olyan tulajdonságokat tart kívánatosnak, amelyek nem biztos, hogy létrehozhatók a településhálózat minden szintjén. A kutatás kiindulópontját a kisvárosok kérdésköre jelentette, amely településtípus aránylag gyakran szerepel a társadalmi tőke, az identitás vagy általában a fejlődést meghatározó helyi tényezők vizsgálatában (Pirisi 2017). Ilyen szempontból a modell kisvárosokra optimalizált; legfontosabb sajátossága, hogy a kisebb településméret esetén illúziónak tűnik a gazdasággal szemben megfogalmazott diverzitási kritérium vagy a fejlődéshez szükséges források feletti kontroll, autonómia. A településméret növekedésével általában a kohézió fenntartása tűnik a legnagyobb kihívásnak.

\section{Összefoglalás és a kutatás tervezett további irányai}

Az ökológiaitól egyre inkább elszakadó, társadalmi értelmezést is kapó reziliencia mint értelmezési-elemzési keret helyet követel magának a települési vizsgá- 
latokban. Figyelmen kívül hagyását a társadalomföldrajz aligha engedheti meg magának: előnye, hogy integráltan kezel több, korábban egymástól többé-kevésbé elválasztott sajátosságot. Új értelmezését kínálja a települések és régiók fejlődésének, kellő mennyiségű empirikus kutatási tapasztalat birtokában segíthet a tervezés, a fejlesztéspolitika és a településmenedzsment sikeresebbé tételében.

A tanulmányban felvázolt elméleti modell a reziliencia egy, de korántsem egyetlen értelmezését és alkalmazását tartalmazza. Mint minden hasonló modell, legalább annyit elárul a szerzőről, mint magáról a tárgyról. A kisvárosok kutatása során került előtérbe válságuk társadalmi aspektusa, amelyet nemcsak a népességszám zsugorodása, hanem a társadalmi kapcsolatok átalakulása is jelez. A modell jelenlegi felépítése azt sugallja, hogy ezek a társadalmi kapcsolatok döntő szerepet játszhatnak abban, hogy a települések jobb helyekké, magasabb életminőséget nyújtó, elégedettebb embereknek otthont adó közösségekké váljanak.

Az elméleti modell publikálása mellett részben lezajlott empirikus tesztelése is. Jelenleg is folynak azok a kutatások baranyai kisvárosokban, amelyek helyi tapasztalatokkal töltik fel a modellt - nem annyira az egyes jellemzőket számszerűsítve, hanem inkább elhelyezve őket egy relatív skálán és meghatározva változásuk irányát. A nyitott kérdések közé tartozik, hogy az egyes elemek pozitív vagy negatív visszacsatolásai hogyan alakulnak, megállják-e helyüket az előbbiekben ismertetett összefüggések. Végül, de nem utolsósorban izgalmas kérdés, hogy a hazai viszonyok milyen árnyalatot adnak hozzá a reziliencia értelmezési lehetőségeihez. Vajon nem járunk-e tévúton, amikor kohéziót, autonómiát és diverzitást emlegetünk és ezek egymásra hatását vizsgáljuk, és nem kellene a rugalmas alkalmazkodást egyszerủen a hatalmi struktúrákba való sikeres beilleszkedés termékeként értékelnünk? A helyi sajátosságokon túl falvak, kis- és nagyvárosok fejlődésének meghatározó kihívásai egyre inkább a globális környezetből jönnek, így ennek felismerése mellett az ellenhatásként megerősödő lokalitásra fordított figyelem kifizetődőbbnek tünik, mint a nemzeti keretből fakadó sajátosságok értelmezése.

\section{Köszönetnyilvánítás}

A szerző munkáját az MTA Bolyai János Ösztöndíja támogatta.

\section{Irodalom}

Adger, N. W. (2000): Social and ecological resilience: are they related? Progress in Human Geography, 3., 347-364. http://doi.org/df956b 
Adger, W. N., Hughes, T. P., Folke, C., Carpenter, S. R., Rockström, J. (2005): Social-ecological resilience to coastal disasters. Science, 5737., 1036-1039. http://doi.org/bg6vps

Ahern, J. (2011): From fail-safe to safe-to-fail: Sustainability and resilience in the new urban world. Landscape and Urban Planning, 4., 341-343. http://doi.org/cpzmb2

Aldrich, D. P., Meyer, M. A. (2015): Social capital and community resilience. American Behavioral Scientist, 2., 254-269. http://doi.org/f6tr2d

Alpek B. L., Máté É. (2018): „Nagyon el vagyunk ám itt zárva” - izolálódó települések a BaranyaiHegyháton. Településföldrajzi Tanulmányok, 1., 70-91.

Alpek B. L., Tésits, R. (2014): A munkaerő-piaci szenzitivitás. Új módszer a magyarországi munkaerőpiac területi, térszerkezeti kérdéseinek feltárásában. Területi Statisztika, 4., 333-359.

Bándi Gy. (2013): Hozzászólás a túlélés szellemi kör üzenetéhez egy jogász szemével. Magyar Tudomány, 9., 1119-1125.

Barata-Salgueiro, T., Erkip, F. (2014): Retail planning and urban resilience - An introduction to the special issue. Cities, 36., 107-111. http://doi.org/c4hk

Barr, S., Devine-Wright, P. (2012): Resilient communities: sustainabilities in transition. Local Environment, 5., 525-532. http://doi.org/c4hm

Békés V. (2002): A reziliencia-jelenség, avagy az ökologizálódó tudományok tanulságai egy ökologizált episztemológia számára. In: Forrai G., Margitay T. (szerk.): „Tudomány és történet” - Tanulmánykötet Fehér Márta tiszteletére. Typotex, Budapest, 215-228.

Berkes, F., Folke, C. (1998): Linking social and ecological systems for resilience and sustainability. Cambridge University Press, Cambridge

Bonanno, G. A. (2004): Loss, trauma, and human resilience: have we underestimated the human capacity to thrive after extremely aversive events? American Psychologist, 1., 20-28. http://doi.org/ccj565

Boros, L., Fabula, Sz., Horváth, D., Kovács, Z. (2016): Urban diversity and the production of public space in Budapest. Hungarian Geographical Bulletin, 3., 209-224. http://doi.org/cbth

Boschma, R. (2015): Towards an evolutionary perspective on regional resilience. Regional Studies, 5., 733-755. http://doi.org/f3n45d

Callaghan, E. G., Colton, J. (2008): Building sustainable \& resilient communities: a balancing of community capital. Environment, Development and Sustainability, 6., 931-942. http://doi.org/cwkvh6

Campanella, T. (2006): Urban resilience and the recovery of New Orleans. Journal of the American Planning Association, 2., 141-146. http://doi.org/cgcp4p

Carpenter, S. R., Westley, F., Turner, M. G. (2005): Surrogates for resilience of social-ecological systems. Ecosystems, 8., 941-944. http://doi.org/drjdmd

Chandler, D. (2014): Beyond neoliberalism: resilience, the new art of governing complexity. Resilience, 1., 47-63. http://doi.org/c4hn

Coaffee, J. (2008): Risk, resilience, and environmentally sustainable cities. Energy Policy, 12., 4633-4638. http://doi.org/b9h5vf

Colding, J., Elmqvist, T., Olsson, P. (2003): Living with disturbance: building resilience in socialecological systems. In: Berkes, F., Colding, J., Folke, C. (eds.): Navigating social-ecological systems: building resilience for complexity and change. Cambridge University Press, Cambridge, 163-185. http://doi.org/bx5v5b

Colten, C., Sumpter, A. (2009): Social memory and resilience in New Orleans. Natural Hazards, 3., 355-364. http://doi.org/c7z53q

Cutter, S. L. (2016): Resilience to what? Resilience for whom? The Geographical Journal, 2., 110-113. http://doi.org/c4hp

Deppisch, S. (2016): Urbane sozial-ökologische Resilienz. In: Wink, R. (Hrsg.): Multidisziplinäre Perspektiven der Resilienzforschung, Springer Fachmedien, Wiesbaden, 199-213. http://doi.org/c4hq

Elmqvist, T., Folke, C., Nystrom, M., Peterson, G., Bengtsson, J., Walker, B., Norberg, J. (2003): Response diversity, ecosystem change, and resilience. Frontiers in Ecology and the Environment, 9., 488-494. http://doi.org/bwdf53

Faragó L. (2017): Autopoietikus (társadalmi) terek koncepciója. Tér és Társadalom, 1., 7-29. http://doi.org/c4hr

Fejérdy T., Z. Karvalics L. (2015): Kis- és közepes városok kulturális reziliencia-súlypontjai. Replika, 94., 113-127. 
Folke, C. (2006): Resilience: The emergence of a perspective for social-ecological systems analyses. Global Environmental Change, 3., 253-267. http://doi.org/bm28fh

Greenberg, M., Gotham, K. F. (2008): From 9/11 to 8/29: Post-disaster recovery and rebuilding in New York and New Orleans. Social Forces, 2., 1039-1062. http://doi.org/c238jj

Gyáni G. (2008): Identitás, emlékezés, lokalitás. 2000 - Irodalmi és Társadalmi Havilap, 6.

Hajnal K. (2006): A fenntartható fejlődés elméleti kérdései és alkalmazása a településfejlesztésben. PhD-értekezés. PTE TTK Földtudományok Doktori Iskola, Pécs

Hassink, R. (2010): Regional resilience: a promising concept to explain differences in regional economic adaptability? Cambridge Journal of Regions, Economy and Society, 1., 45-58. http://doi.org/b6925s

Holling, C. S. (1973): Resilience and stability of ecological systems. Annual Review of Ecology and Systematics, 1., 1-23.

Holling, C. S. (1986): The resilience of terrestrial ecosystems: local surprise and global change. In: Clark, W. C., Munn, R. E. (eds.): Sustainable development of the biosphere. Cambridge University Press, Cambridge, 292-320.

Holling, C. S. (2000): Theories for sustainable futures. Conservation Ecology, 2., 7. http://doi.org/c4hs

Holling, C. S. (2001): Understanding the complexity of economic, ecological and social systems. Ecosystems, 5., 390-405. http://doi.org/b77bt5

Kaltenbrunner, R. (2013): Mobilisierung gesellschaftlicher Bewegungsenergien - Von der Nachhaltigkeit zur Resilienz - und retour? Informationen zur Raumentwicklung, 4., 287-296.

Keogh, D. U., Apan, A., Mushtaq, S., King, D., Thomas, M. (2011): Resilience, vulnerability and adaptive capacity of an inland rural town prone to flooding: A climate change adaptation case study of Charleville, Queensland, Australia. Natural Hazards, 2., 699-723. http://doi.org/dx2mjm

Kirmayer, L. J., Dandeneau, S., Marshall, E., Phillips, M. K., Williamson, K. J. (2011): Rethinking resilience from indigenous perspectives. The Canadian Journal of Psychiatry, 2., 84-91. http://doi.org/c4ht

Kovács Z., Szabó B. (2017): A városi diverzitás jellemzői Budapesten a rendszerváltozás után. Regio, 4., 57-79. http://doi.org/c4hv

Lang, T. (2011): Urban resilience and new institutional theory - A happy couple for urban and regional studies? In: Müller, B. (ed.): German Annual of Spatial Research and Policy. Springer, Berlin, Heidelberg, 9-18. http://doi.org/cpxrmw

Lang, T. (2012): How do cities and regions adapt to socio-economic crisis? Towards an institutionalist approach to urban and regional resilience. Raumforschung und Raumordnung. 4., 285-291. http://doi.org/c4hw

Lendvay, M. (2016): Resilience in post-socialist context: The case of a watermelon producing community in Hungary. Hungarian Geographical Bulletin, 3., 225-269. http://doi.org/c4hx

MacKinnon, D., Derickson, K. D. (2013): From resilience to resourcefulness. Progress in Human Geography, 2., 253-270. http://doi.org/f42csq

Majtényi Gy. (2015): "De elmehet a Kádár Jani a picsába!” Reziliencia az államszocializmusban. Replika, 94., 92-112.

Martin, R. (2012): Regional economic resilience, hysteresis and recessionary shocks. Journal of Economic Geography, 1., 1-32. http://doi.org/bcb6pd

Martin, R., Sunley, P. (2015): On the notion of regional economic resilience: Conceptualisation and explanation. Journal of Economic Geography, 1., 1-42. http://doi.org/f64gsj

Molnár E. (2014): Gazdasági útkeresés a tanulás jegyében - egy alföldi kisváros esete. Educatio, 3., $462-471$.

Murányi I., Szoboszlai Zs. (2000): Identitás-jellemzők a dél-alföldi régióban. Tér és Társadalom, 1., 27-50. http://doi.org/c4hz

Németh Á. (2016): Diversity studies: új társadalomtudományi paradigma? Regio, 2., 203-218. http://doi.org/c4h2

Németh Á., Dövényi Z. (2014): A vallási diverzitás változása Magyarországon 2001 és 2011 között. Területi Statisztika, 6., 550-573.

Norris, F., Stevens, S., Pfefferbaum, B., Wyche, K. F., Pfefferbaum, R. L. (2008): Community resilience as a metaphor, theory, set of capacities, and strategy for disaster readiness. American Journal of Community Psychology, 1-2., 127-150. http://doi.org/cwnpf4 
Pálné Kovács, I., Bodor, Á., Finta, I., Grünhut, Z., Kacziba, P., Zongor, G. (2016): Farewell to decentralisation: The Hungarian story and its general implications. Hrvatska i Komparativna Javna Uprava, 4., 789-816. http://doi.org/c4h3

Pap Á. (2014): Az épitett örökség és a helyi identitás kapcsolatának cselekvóközpontú földrajzi vizsgálata budapesti mintaterületeken. PhD-értekezés. Szegedi Tudományegyetem, Szeged. http://doi.org/c4h4

Peck, J., Tickell, A. (2002): Neoliberalizing space. Antipode, 3., 380-404. http://doi.org/drnfbk

Petzold, J. (2016): Limitations and opportunities of social capital for adaptation to climate change: a case study on the Isles of Scilly. The Geographical Journal, 2., 123-134. http://doi.org/f854x6

Pirisi G. (2017): A reziliencia szerepe a kisvárosok fejlődésében - egy komlói esettanulmány kapcsán. Településföldrajzi Tanulmányok, 2., 75-88.

Pirisi, G., Trócsányi, A. (2015): Shrinking small towns in Hungary: the factors behind the urban decline in "small scale." Acta Geographica Universitatis Comenianae, 2., 131-147.

Plöger, J., Lang, T. (2013): Resilienz als Krisenfestigkeit: Zur Anpassung von Bremen und Leipzig an den wirtschaftlichen Strukturwandel. Informationen zur Raumentwicklung, 4., 325-335.

Reggiani, A., Graaff, T. D, Nijkamp, P. (2002): Resilience: an evolutionary approach to spatial economic systems. Networks and Spatial Economics, 2., 211-229. http://doi.org/dtdr6j

Reményi P. (2009): Etnikai homogenizáció a volt Jugoszláviában. In: M Császár Zs. (szerk.): Magyarország és a Balkán. PTE TTK Földrajzi Intézet, Kelet-Mediterrán és Balkán Tanulmányok Központja, Pécs, 122-129.

Renschler, C., Frazier, A., Arendt, L., Cimellaro, G. (2010): Developing the 'PEOPLES' resilience framework for defining and measuring disaster resilience at the community scale resilience. In: Proceedings of the 9th US National and 10th Canadian Conference on Earthquake Engineering. Toronto, 25-29.

Robinson, G., Carson, D. (2016): Resilient communities: transitions, pathways and resourcefulness. The Geographical Journal, 2., 114-122. http://doi.org/f3nwr9

Sieverts, T. (2013): Am Beginn einer Stadtentwicklungsepoche der Resilienz? Folgen für Architektur, Städtebau und Politik. Informationen zur Raumentwicklung, 4., 315-323.

Simmie, J. (2014): Regional economic resilience: a Schumpeterian perspective. Raumforschung und Raumordnung, 2., 103-116. http://doi.org/c4h5

Simmie, J., Martin, R. (2010): The economic resilience of regions: towards an evolutionary approach. Cambridge Journal of Regions, Economy and Society, 1., 27-43. http://doi.org/bzjfg3

Somers, S. (2009): Measuring resilience potential: An adaptive strategy for organizational crisis planning. Journal of Contingencies and Crisis Management, 1., 12-23. http://doi.org/d2bnpk

Strange, S. (1996): The tetreat of the state: The diffusion of power in the world economy. Cambridge University Press, Cambridge

Stumpp, E-M. (2013): New in town? On resilience and "resilient cities." Cities, 32., 164-166. http://doi.org/f44r7p

Swanstrom, T. (2008): Regional resilience: a critical examination of the ecological framework. IURD Working Paper Series, Institute of Urban and Regional Development, University of California, Berkeley, 1-34.

Szabó B. (2015): Reziliens városok. Erdélyi Társadalom, 1., 73-83.

Székely I. (2015): Reziliencia: a rendszerelmélettől a társadalomtudományokig. Replika, 94., 7-23.

Szokolszky Á., V. Komlósi A. (2015): A „reziliencia-gondolkodás” felemelkedése - Ökológiai és pszichológiai megközelítések. Alkalmazott Pszichológia, 1., 11-26. http://doi.org/c4h6

Tanner, T., Mitchell, T., Polack, E. (2009): Urban governance for adaptation: assessing climate change resilience in ten Asian cities. IDS Working Papers, 315, 1-47. http://doi.org/ck59rd

Tierney, K., Bruneau, M. (2007): Conceptualizing and measuring resilience: A key to disaster loss reduction. TR News, 250., 14-17.

Tóth B. I. (2012): Regionális rugalmasság - rugalmas régiók. Tér és Társadalom, 2., 3-21. http://doi.org/c4h7

Tóth, B. I. (2015): Regional economic resilience: Concepts, empirics and a critical review. Miscellanea Geographica, 3., 70-75. http://doi.org/c4h8

Townshend, I., Awosoga, O., Kulig, J., Fan, H. Y. (2016): Social cohesion and resilience across communities that have experienced a disaster. Natural Hazards, 2., 913-938. http://doi.org/f63mqv 
Tschakert, P., Tamminga, K. R., Prins, E., Dietrich, K., Tamminga, K., Shaffer, J., Asiedu, A. (2014): Learning and envisioning under climatic uncertainty: An African experience. Environment and Planning A, 5., 1049-1068. http://doi.org/f6qz76

V. Komlósi A., Richter J. (2015): Az egyéni és a közösségi reziliencia kapcsolata a vörösiszap-katasztrófa tapasztalatainak fényében. Alkalmazott Pszichológia, 1., 61-76. http://doi.org/c4h9

Walker, B., Holling, C. S., Carpenter, S. R., Kinzig, A. (2004): Resilience, adaptability and transformability in social-ecological systems. Ecology and Society, 2., 5. http://doi.org/gc6v5q

Watts, M. (2016): From vulnerability to resilience: Hans-Georg Bohle's scholarship and contemporary political ecology. Die Erde, 4., 252-265.

Werner, E. (1989): High-risk children in young adulthood: A longitudinal study from birth to 32 years. American Journal of Orthopsychiatry, 1., 72-81. http://doi.org/dpd72g

Wink, R. (2014): Regional economic resilience: European experiences and policy issues. Raumforschung und Raumordnung, 2., 85-91. http://doi.org/c4jc 